\title{
UNETHICAL BEHAVIOUR IN HUMAN RESOURCE MANAGEMENT PRACTICES IN SOUTH AFRICA: VIEWS OF HUMAN RESOURCE PRACTITIONERS
}

\author{
Barney J. Erasmus*
}

Received: 7. 2. 2018

Preliminary communication

Accepted: 16. 7. 2018

UDC 005.95/96:17(6-13)

DOI https://doi.org/10.30924/mjcmi/2018.23.1.65

\begin{abstract}
The study on which this article reports, examined the relationship between the susceptibility of unethical behaviour in human resource (HR) practices (dependent variable) and three independent variables, namely the role of the HR function in institutionalising good business ethics, factors influencing the personal ethical behaviour of HR practitioners, and the commitment to ethical business conduct, exhibited by certain individuals and groups within organisations. A descriptive study was undertaken using an online questionnaire, and $304 \mathrm{HR}$ practitioners in South Africa participated. The results indicated that employee selection, performance management and appraisal, recruitment and advertising were the areas most susceptible to unethical HR practices. The least susceptible
\end{abstract}

\section{INTRODUCTION}

The decline in ethical behaviour in government and corporate South Africa is disquieting (Van der Walt et al., 2016). The findings of the 2016 Business Ethics survey indicate that there has been "little change in creating ethics awareness and communication program" in South African companies since 2013, economic growth
$H R$ areas were affirmative action, employment equity plans, employee orientation, employee socialisation, and psychometric testing. The results also showed statistically significant relationships among the independent variables and the dependent variable. Amongst others findings, a statistically significant positive relationship existed between susceptible unethical HR practices when HR practitioners are solely responsible for resolving ethical dilemmas, and a negative relationship when HR is not directly involved with resolving ethical dilemmas. The HR function has an important role and contributes to institutionalising business ethics in organisations.

Key words: Human Resource Management, ethics, South Africa, practitioners' views

is ailing and, in addition, staff in organisations are under tremendous pressure to perform (Groenewald, 2016:16). Corruption in Africa remains pervasive (Barney, 2017; Luiz \& Stewart, 2014), and Corruption Watch (a non-profit organisation working to fight corruption) in South Africa is of the view that "Corporate South Africa is not taking ethics seriously enough" (Corruption

\footnotetext{
* Barney J Erasmus, Department of Business Management, Samuel Pauw Building, Room 5-48, Muckleneuk, Pretoria, South Africa. University of South Africa, PO Box 392, Unisa, 0003, Telephone: 012433 4681, Email: erasmbj@unisa.ac.za or erasmbj@gmail.com
} 
Watch, 2016:1). In an environment, which is endemic with unscrupulous behaviour, it is becoming increasingly difficult to make ethical decisions or to objectively assess the implications of decisions in particular within the organisational context. This dilemma places the responsibility on the leadership of all organisations - especially the HR function as a strategic role player and an enabler - to inculcate an ethical culture to ensure optimal organisational performance (Caldwell et al., 2011; Kleiman, 1997; Ulrich, 2017). The questions to be considered are: what is the "right thing to do?" and what is "right for the greater good of the organization?" (Linehan \& O'Brien, 2017:763).

The aim of this study was to report on the views of human resource practitioners on the susceptibility of unethical behaviour in HR practices in South African organisations, in particular the relationship between the aforementioned practices and three independent variables, namely the role of the HR function in institutionalising good business ethics, factors influencing the personal ethical behaviour of HR practitioners in the workplace, and whether the amount of commitment to ethical business conduct exhibited by certain individuals and groups within their organisations is sufficient. By establishing these relationships, a significant contribution is made to obtain a deep understanding and fill the gap in literature of HR practices susceptible to unethical behaviour in South African organisations.

\section{LITERATURE REVIEW}

The focus of the literature review will be on the importance of organisational ethical frameworks, ethics in HR management, and the importance of leadership levels in ensuring an ethical organisation.

\subsection{Ethics in organisations and ethical frameworks}

Organisations operate in a complex global business environment and face a multitude of ethical issues. These fundamental ethical issues include concepts such as "integrity and trust", but also more complex matters such as respecting diversity, decision-making, compliance, and governance (Oster, 2017). Ethics in general refers to a system of good and bad, moral and immoral, fair and unfair, whilst ethics in business is the study and the application of what constitutes right and wrong, good, or bad in the business environment (De George, 2015; Prasad et al., 2017; Shaw, 2017). Business ethics is all-inclusive, does not exclude any organisational activity and is mainly affected by culture, religion and legislation (Bernstein, 2016).

To enable organisations to manage ethics strategically, it is advisable to have a holistic organisation ethical framework. According to the Ethics Centre (2016), an ethical framework is a fundamental articulation of what an organisation seeks to achieve. Three ethical frameworks are briefly outlined. Firstly, Spence (2014) considers ethics from a small business context and highlights moral proximity and social care as possible frameworks. In this regard, the emphasis should be on relationships and not on outcomes and elements such as valuing emotions, impartiality and inclusivity, meeting the needs of those for whom we take responsibility, and accepting that people are rational and independent beings. Secondly, the Ethics Centre (2016) posits that the foundation of an ethical framework should include a purpose statement, values and principles, which are feasible, reliable, constant and comprehensible. Thirdly, Svensson and Wood (2011) contribute to the topic by suggesting a conceptual framework with four separate areas, namely 
across the organisation, ethical structures, ethical processes, and ethical performance. The area of ethical performance serves the purpose of evaluating and maintaining ethical business practices across organisations, such as the role of the HR function in supporting ethical behaviour, such as introducing business codes (Hijal-Moghrabi et al., 2015; Kaptein \& Schwartz 2008). Kaptein (2011:233) defines business codes as "prescriptions developed by an organisation to guide the behaviour of managers and employees". These codes are seen as the most effective instrument for preventing unethical work behaviour. However, Kaptein (2015a) reports that the success of an ethics programme is contingent on the design and implementation process. Ruiz et al.(2014) posit that for a code of ethics to have real meaning and effectiveness, it should be implemented in concert with other ethics-related components (Kaptein \& Schwartz 2008). The everchanging internal and external environment and dynamic nature of ethical dilemmas to be solved place a very important responsibility on HR to introduce new policies and codes, and to review and delete outdated policies and codes (Skeet, 2017).

With regard to codes, Wiley (2000) studied five key professional ethics HR codes in the United States of America, and the results support five principles linked to integrity, legality, proficiency, loyalty, and confidentiality but mention that not much is reported on sanctions and penalties. The South African Board for People Practices (SABPP), as the professional body for HR in South Africa, guides registered members by a code of conduct and a competency model. The foundation of the HR competency model consists of four pillars, namely duty to society, professionalism, business knowledge, and ethics (SABPP HR competency model, 2017). Furthermore, all members of the SABPP are expected to adhere to the SABPP ethical code, stipulating the SABPP's ethical identity as responsibility, integrity, respect, and competence, and members are therefore ethically obliged to bring meaning and quality of work life to the people they serve (SABPP Code of Ethics, 2017).

\subsection{Ethics and the human resource function}

Ethics in HR management has become a regular debate within organisations (Rose, 2017) and there is no doubt that people are the most important factor in any organisation and crucial for outstanding organisational performance (Boyne, 2003; Hijal-Moghrabi et al., 2015). Greenwood (2013:355) is of the view that "Human resource management is inherently ethical activity and in that its fundamental core is concerned with the treatment of humans" (Harned, 2005). These authors are supported by McDonald (2013:1) who posits, "Ethics should be thought of as the heart of an organization's HR function." Losey (1997:296-301) suggests that HR competency must also be "strengthened by advocacy and ethics and that the latter is important for all professions but more so for $H R$ professionals because they need to know more than the HR body of knowledge".

Managing and preventing unethical behaviour in the workplace is a significant challenge. The question is what unethical behaviour is (Kaptein, 2011) and, according to Kaptein (2008:979), "to be able to answer these questions, sound measures for assessing unethical behaviour are required." Unethical behaviour is viewed as behaviour that violates generally accepted moral norms, organisational policies, codes, and the risks, if not managed, are high for organisations, stakeholders and society (Karpoff et al., 2008). 
The HR function deals with a variety of ethical challenges, and covers all those ethical issues arising around the employeremployee relationship, such as the rights and duties allocated between employer and employee (Ingram, 2017; Singh 2017), discrimination issues, sexual harassment and unfair employment policies (Ingram, 2017). Other HR responsibility activities such as HR planning, job analysis (Gibbons, 2015), recruitment and selection (Botha, 2015) induction and orientation, compensation (Honnet, 2015), performance appraisals, training and development (Shapiro, 2015), labour relations, broad-based black economic empowerment (B-BBEE) (Brun, 2015), employment equity and transformation (Abbott, 2015), appointing non-permanent contract labour and employee development activities are part of the HR function (Morley, 2017; Sarker, 2017). Importantly, however, each of these activities could be susceptible to unethical behaviour. Wiley (2000) is of the view that HR practitioners will also be confronted with serious ethical dilemmas, which are difficult to resolve, for example favouritism, inconsistencies, sexual harassment, sexual and racial discrimination, and breaches of confidentiality. Ethical behaviour is about human behaviour (Van Vuuren \& Eiselen, 2006) and organisations consist of humans, and the function responsible for human activities is the HR function of the organisation (McDonald, 2013; Rendtorff, 2018). This does not imply that HR is solely responsible for ethics in organisations but HR does have an important role to play as they have to execute various HR functions from employee induction to exit interviews (Chartered Institute of Personnel and Development - CIPD, 2017).

HR plays a key role in handling important HR issues in the organisation, namely to develop policies and resolve ethical dilemmas (Sims, 2017). One of the most important roles HR plays in an organisation is that of being a transformation and change agent. This requires "a new way of thinking and doing HR which requires a culture and a mind-set change" (Ulrich, 1997: 168). HR professionals should become strategic partners and deliver a service within the context addressing broader ethical issues, in particular those ethical dilemmas within the domain of HR. In addition, these professionals should champion HR within the organisation not only to focus on improving internal organisational efficiencies but also to manage future challenges such as globalisation and sustainability and thereby improve shareholder and customer value (Ulrich \& Dulebohn, 2015).

Jondle et al. (2014:30) assert that cultures "manifest themselves through complex combinations and interplay of formal and informal systems and processes, and formal and informal interactions between organisational members and various outside stakeholders". Culture is, therefore, a shared sense of "how we do things around here' and forms a crucial factor of organisational success (McDonald, 2013; Schminke et al., 2007). When creating an ethical culture in organisations, six key pillars are essential: leadership commitment; ethics goal and strategy; ethical standards; ethics awareness and understanding; ethics recognition and reward; ethics assessment, monitoring and reporting (Schoeman, 2017). Good HR policies, codes and procedures are normally a good start to manage HR processes and instil an ethical culture; however, the responsibility also lies with the chief executive officer (CEO), managers and all employees (Wiley, 2000).

Linehan and O'Brien (2017:775) report on a study where HR practitioners were challenged with ethical dilemmas and reported, 'trying to abide by a 'set' ethical 
code or set of standards is like trying to stand on shifting tectonic plates." The results from a study conducted by Ogwoka et al. (2017) revealed a significant relationship between ethical HR practices and financial performance, which was quantified through a linear regression model. Ghani (2015) suggests that the organisation have to set up procedures that make the workplace seem fair to employees, with ethical leadership displayed at all levels and invoking fairness to control organisational harmony.

\subsection{Ethics and leadership levels}

Ethical leadership is essential for successful organisations (Arshad, 2016; Den Hartog, 2015). Employees, who work with leaders exhibiting high moral standards, integrity and expectations, are encouraged and driven toward successful task achievement (Andrews \& Boyne, 2010; HijalMoghrabi et al., 2015; Lloyd et al., 2014). All levels of management should therefore be responsible to inculcate an ethical culture in superiors, peers and subordinates and set an example. Ethical leaders should be vigilant to foresee possible changes and act upon unethical challenges in advance (Kaptein, 2015b). Small transgression might lead to disastrous consequences in the future (Welsh et al., 2015) and by taking proactive action, may result in new norms, which could assist all employees who are challenged by pressures and temptations, to resolve ethical dilemmas collectively and enhance commitment. Mitonga-Monga and Cilliers' (2016) study showed a strong positive relationship between ethical leadership and organisational commitment.

Middle managers use various handling strategies when dealing with an ethical challenge, and this could influence the overall ethical environment of the organisation positively or negatively (Hiekkataipale \& Lämsä, 2015). An open, proactive and even risk-taking approach to resolving ethical problems seems to strengthen the ethical culture. Where leaders and managers are weakening the ethical cultures, consequence management should be applied and senior leadership should clearly communicate to all that unethical behaviour will not be tolerated (Rossouw, 2011). Various factors influence personal ethical behaviour, namely attitude or behaviour of the CEO, senior management or direct supervisor, one's personal values, internal drive and beliefs, organisational politics and performance pressures, threat of punishment, declining organisational resources, internal competition, ethical standards set by professional bodies and legislation (Sims, 2017; Parkes \& Davis, 2013).

\section{RESEARCH METHODOLOGY}

In this section the research approach, target population, participants' profile and statistical analysis used are discussed.

\subsection{Research approach and target population}

A pragmatist approach using a descriptive study was adopted. The process entailed defining the research population, using an online questionnaire, collecting, processing, and analysing data. Online questionnaires were sent to the target population consisting of 2,962 registered members of the South African Board of People Practice (SABPP) and 304 were returned (9.74\% response rate). The questionnaire was based on a similar survey conducted by Erasmus and Wordsworth $(2004 ; 2006)$.

\subsection{Participants' profile}

The employment numbers indicated that $11.8 \%$ of the respondents worked in organisations employing fewer than 50 
employees, $32.6 \%$ in organisations employing between 50 and 1,000 employees, $29.3 \%$ in organisations employing 1,001 to 5,000 employees, and $26.3 \%$ in organisations employing more than $5,000 \mathrm{em}$ ployees. Thus, the majority of respondents $(55.3 \%)$ worked in organisations employing 1,000 or more people. Representation from industries revealed that the majority of respondents $(20.1 \%)$ were employed in the education and training sectors, manufacturing $(9.2 \%)$, mining $(8.6 \%)$, financial and insurance services $(8.6 \%)$ and $(12.5 \%)$ indicated their industry/sector of employment as "other", which included consultants, the public service and non-profit organisations.

With respect to academic qualifications, $36.5 \%$ had a postgraduate diploma or professional qualification, $25.2 \%$ indicated that they held a bachelor's degree or advanced certificate, and $20.3 \%$ had a master's degree. Regarding the hierarchical positions in organisations, the majority reported that they were HR managers (20.1\%), followed by senior and HR advisors (10.5\%), learning and development managers $(9.5 \%)$ and general HR managers $(8.9 \%)$. The participants represented a highly qualified cohort of practitioners and a high percentage filled senior positions.

\subsection{Statistical analysis}

The Statistical Package for the Social Sciences (SPSS) v. 24 was used to conduct the statistical analysis. Principal axis factoring was used as extraction method and promax as rotation method to determine the underlying factor structure of the set of items related to the aforementioned dimensions respectively. Factor analysis reduces the number of variables to a smaller subset of variables based on variability in the patterns of correlations (Pallant, 2013). A standard multiple linear regression analysis was also applied to determine the directional relationship between the independent and the dependent variables. Regression analysis estimates relationships between independent variables and a dependent variable (Pardoe, 2017; Saunders et al., 2009). According to Gallo (2015), the dependent variable is the main factor that you are trying to understand or predict, and the independent variables are the factors you suspect have an influence on the dependent variable.

\section{RESULTS AND DISCUSSION}

This section reports on the results obtained from analysing the three independent variables and the dependent variable and concludes with the results and a discussion of a regression analysis. Figure 1 provides an overview of the independent and dependent variables with the associated items used in this study.

\subsection{The role of the HR function in managing ethics in South African organisations}

The respondents were requested to indicate whether they agreed or disagreed with a number of statements, which dealt with the role of the HR department in managing ethics initiatives (independent variable). This was done using a five-point Likerttype scale $(1=$ strongly disagree and $5=$ strongly agree). The findings are reported in Table 1 below.

There was little agreement among respondents that HR departments are the primary resources for the organisation's ethics initiatives $(X=3.33)$ and that they are often tasked to assist with "cleaning up messes' caused by unethical actions $(X=3.11)$. The respondents' agreement was stronger where the individual/department charged with ethical oversight in organisations was 


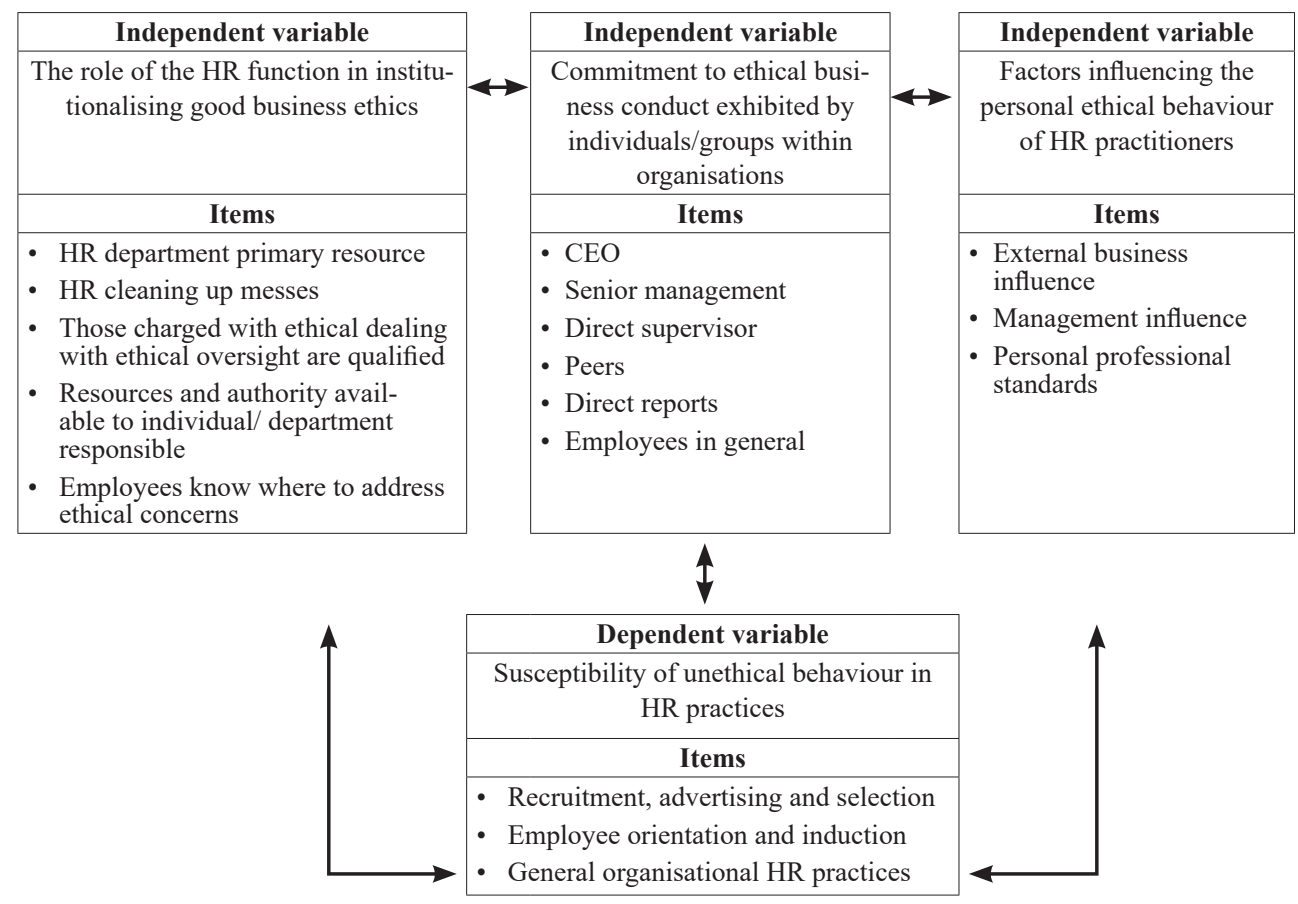

Figure 1: Overview of independent and dependent variables used in the regression analysis.

Table 1: The role of the HR function in managing ethics in an organisation

\begin{tabular}{|c|c|c|c|}
\hline $\begin{array}{l}\text { The role of the HR function in managing ethics } \\
\text { in an organisation }\end{array}$ & $\mathbf{N}$ & Mean & Standard deviation \\
\hline $\begin{array}{l}\text { 1. The HR department is the primary resource of my organisa- } \\
\text { tion's ethics initiatives. }\end{array}$ & 304 & 3.33 & 1.214 \\
\hline $\begin{array}{l}\text { 2. HR professionals are not part of the ethics infrastructure in } \\
\text { my organisation, but they are often tasked with 'cleaning up } \\
\text { messes' caused by unethical actions. }\end{array}$ & 304 & 3.11 & 1.326 \\
\hline $\begin{array}{l}\text { 3. The individual/department charged with ethical oversight in } \\
\text { my organisation is qualified for the task. }\end{array}$ & 304 & 3.67 & 1.074 \\
\hline $\begin{array}{l}\text { 4. The individual/department charged with ethical oversight in } \\
\text { my organisation has at their disposal the resources and au- } \\
\text { thority required to do so. }\end{array}$ & 304 & 3.63 & 1.076 \\
\hline $\begin{array}{l}\text { 5. Employees in my organisation know where to address their } \\
\text { ethical concerns. }\end{array}$ & 304 & 3.63 & 1.191 \\
\hline
\end{tabular}

qualified for the task $(X=3.67)$ followed by those departments who have the resources and authority $(X=3.36)$ required and where employees know where to address ethical concerns $(X=3.63)$. Compared to the results of an earlier study by Erasmus and Wordsworth (2006), it appeared that the role of the HR department as primary resource of organisational ethical initiatives is seen as playing a less significant role in managing ethics. According to Groenewald (2016), more than half of employees in South Africa (52.9\%) prefer to report misconduct to their managers, and $11.9 \%$ 
report it to the HR. This may suggest that employees have more trust in their managers than in the HR and that the creation of separate independent departments/units could be impartial when reporting on the state of ethics in organisations. It is, however, clear that the role of HR as a direct reporting department has become less prominent in dealing with ethical HR matters. This finding calls for an introspection by HR practitioners to redefine and claim their rightful role within organisations.

\subsection{Degree of commitment to ethical business conduct exhibited by managers and various groups in their organisations}

The respondents also had to indicate whether they considered the degree of commitment (indicated as a percentage) to ethical business conduct exhibited by various individuals or groups in their organisations to be sufficient (independent variable). The perceived commitment to ethical conduct was generally high with the CEO $(81.0 \%)$ being perceived as the most committed followed by their direct supervisors $(75.0 \%)$, those they supervise $(74.4 \%)$, senior management $(74.1 \%)$, their peers $(70.3 \%)$ and employees in general, who were rated as the least committed (65.1\%).

\subsection{Factors affecting personal ethical behaviour in the workplace}

The respondents were required to indicate the extent to which a number of factors affected their personal ethical behaviour in the workplace (independent variable) (1 $=$ not at all influential; $5=$ extremely influential). The results, in order of priority (expressed in terms of means), are as follows (see Table 3 ). The top six factors were personal values and beliefs $(4.56 \%)$, ethical standards within the profession $(4.15 \%)$, legislation $(3.80 \%)$, personal internal drive to succeed (3.75\%), attitudes/behaviour of the respondent's direct supervisor (3.71\%), and attitudes/behaviour of the CEO $(3.69 \%)$. The bottom four factors were political pressures $(2.23 \%)$, internal competition $(2.42 \%)$, declining resources $(2.58 \%)$, and friends/co-workers (2.59\%).

To reduce the number of variables to a smaller subset of variables based on variability in the patterns of correlations, the results of a factor analysis for personal ethical behaviour is provided in Table 2 .

The Kaiser-Meyer-Olkin (MKO) measure of sampling adequacy was 0.855 , thus above the recommended threshold of 0.5 and the Bartlett's test of sphericity was statistically significant $(\mathrm{p}<.0001)$ for the personal ethical behaviour items, indicating that a factor analysis was appropriate.

Three factors were identified (Table 2) based on the eigenvalue criterion (eigenvalue greater than 1). These factors cumulatively explained $58 \%$ of the variance. As the Cronbach's alpha coefficient values were above the acknowledged threshold of 0.6 for exploratory research (Hair et al., 2010), the reliability of all three factors were considered satisfactory. The items that clustered on the same factor suggested that factor 1 represented internal and external business influence factors (mean $=2.83$, SD .997), while the items of factor 2 indicated management influence $($ mean $=3.66$, SD 1.25) and the items of factor 3 indicated influence of personal and professional standards $($ mean $=4.17$, SD .775).

\subsection{HR practices susceptible to unethical behaviour}

The respondents were required to indicate the degree to which they perceived specific HR practices to be susceptible to unethical practice (dependent variable). The 
Table 2: Factor analysis for factors influencing personal ethical behaviour

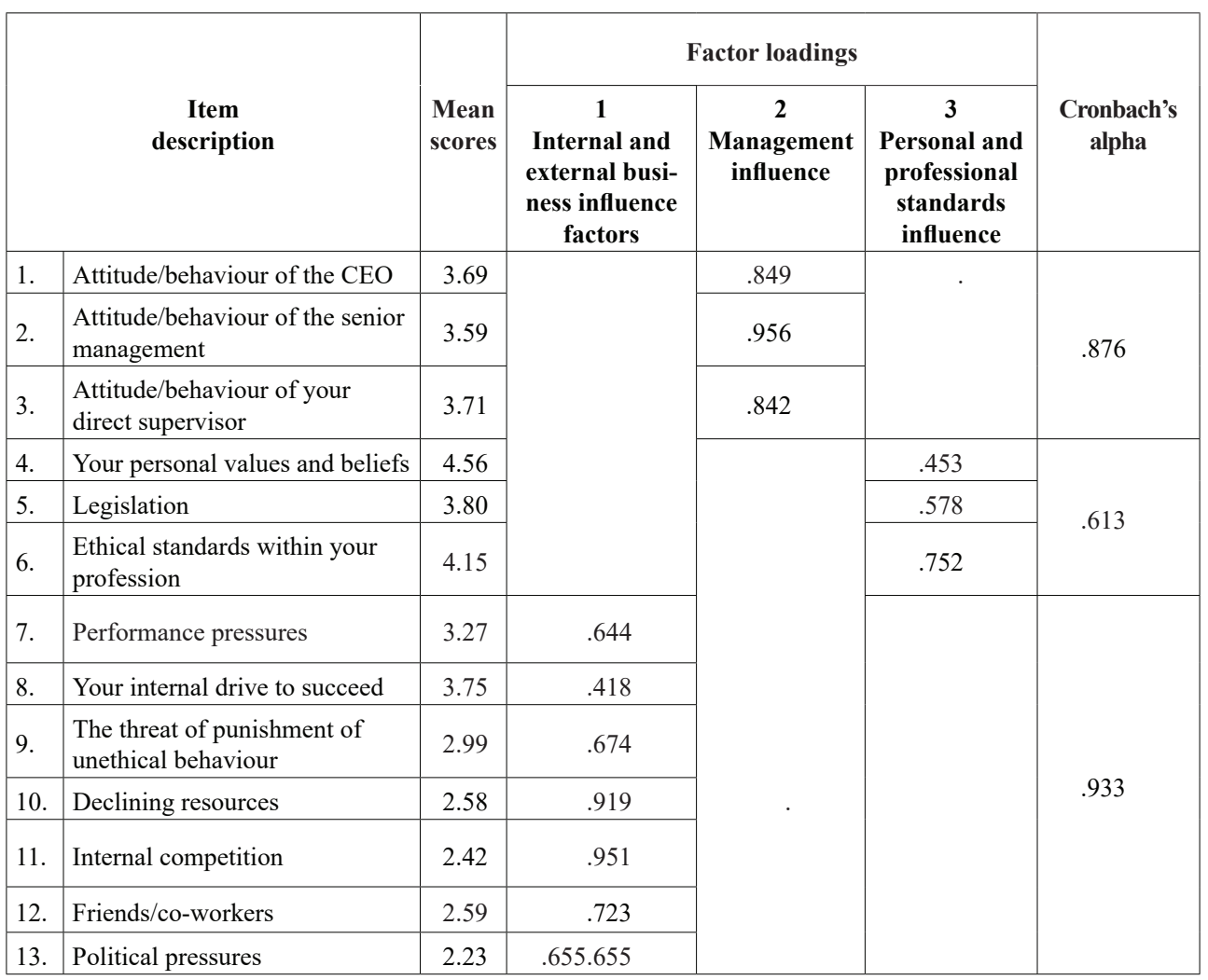

responses were recorded on a sliding scale, where 0 represented "very little likelihood of unethical practice" and 10 represented "highly susceptible to unethical practice". According to the respondents, the following four HR practices were highly susceptible: employee selection, performance management and appraisal, recruitment and advertising, and remuneration and reward. The HR practices least susceptible to unethical conduct were affirmative action and employment equity plans (regulated by the Employment Equity Act in South Africa whose purpose is to address unfair discrimination and ensure equality in the work place), employee orientation and induction, employee socialisation, and psychometric and occupational testing. It is important to note that any form of psychological assessment in South Africa is controlled within an extensive regulatory legal framework (Muleya et al., 2017). The latter is most likely the reason why psychometric and occupational testing (which in this study was listed separately) was considered one of the HR practices least susceptible to unethical conduct.

To reduce the number of variables to a smaller subset of variables based on variability in the patterns of correlations, a factor analysis on susceptible unethical HR practices was performed and the results are provided in Table 3.

The KMO measure of sampling adequacy was 0.942 , which is above the 
recommended threshold of 0.5 , and the Bartlett's test of sphericity was statistically significant $(\mathrm{p}<.001)$ indicating that a factor analysis was appropriate.

Three factors were identified (Table 3) based on the eigenvalue criterion (eigenvalue greater than 1). They cumulatively explained $60 \%$ of the variance. As the Cronbach's alpha coefficient values were above the acknowledged threshold of 0.6 for exploratory research (Hair et al., 2010), the reliability of all three factors were considered satisfactory. The items that clustered on the same factor suggested that factor 1 represented recruitment and selection (mean $=6.13$, SD $=2.976$ ), the items of factor 2 indicated employee orientation and socialisation (mean = 2.54, SD 2.365), and the items of factor 3 indicated various organisational HR practices $($ mean $=4.37$ SD 2.449). As the Cronbach's alpha coefficient values were above the acknowledged threshold of 0.7 for research, the reliability of all three factors were considered satisfactory

\subsection{The relationship between the independent and dependent variables: multiple regression analysis}

Table 4 reflects the results of multiple regression analyses. Here, the relationship between independent variables (predictor or explanatory) and dependent variable was investigated (see Figure 1). The independent variables were: factors influencing the respondents' personal ethical behaviour in the workplace, degree of commitment to ethical business conduct by certain individuals or groups within their organisations and the role of the HR function in organisations. The dependent variable, namely the susceptibility of unethical behaviour in HR practices is presented below (see Table 4). The intent of the regression analysis was only to determine the statistically significant predictors and the strength and direction (positive or negative) of the relationship by utilising the standardised beta weights and the statistical significance of the beta coefficient. It was not the purpose of the research to utilise this model as a predictive model.

Potential multicollinearity between the set of independent variables was tested using the tolerance/variance inflation factor (VIF). The thresholds of at least 0.1 but not larger than 10 were used to assess multicollinearity. None of the tolerance/variance inflation factor values exceeded the thresholds. Thus, no multicollinearity was present in the regression models tested.

The results of model 1, 2 and 3 indicated that the $\mathrm{R}^{2}$ values were very low and showed that very little variation in the dependent variable. Unethical HR practices factors 1, 2 and 3 can be explained by the respective set of independent variables in each model. However, the statistical significance indicated by the $\mathrm{F}$ test for regression (the beta coefficients differ significantly from 0 ) with $\mathrm{p}$-values indicating statistical significance at $5 \%$ and $10 \%$ respectively indicating that the independent variables did play a role in explaining the dependent variables. The standardised beta values and associated statistical significance are provided below.

\subsubsection{Unethical HR practices: Recruitment, advertising and selection (Model 1).}

The degree to which the recruitment, advertising, and employee selection practices are susceptible to unethical HR practises was statistically significantly influenced by:

a) "personal ethical behaviour" factor 3, namely "the respondents' personal and professional standards influence" (positive relationship $\mathrm{p}<0.05, \mathrm{~b}=0.175$ ). The higher they indicated the "personal and professional standard" influences, 
Management, Vol. 23, 2018, No.2, pp. 65-86 B. J. Erasmus: UNETHICAL BEHAVIOUR IN HUMAN RESOURCE...

Table 3: Factor analysis for "susceptible unethical HR practices"

\begin{tabular}{|c|c|c|c|c|c|c|}
\hline & \multirow[b]{2}{*}{ Item description } & \multirow[b]{2}{*}{$\begin{array}{l}\text { Mean } \\
\text { scores }\end{array}$} & \multicolumn{3}{|c|}{ Factor loadings } & \multirow[b]{2}{*}{$\begin{array}{c}\text { Cronbach's } \\
\text { Alpha }\end{array}$} \\
\hline & & & $\begin{array}{c}\text { Factor } 1 \\
\text { Recruitment } \\
\text { and selection }\end{array}$ & $\begin{array}{c}\text { Factor } 2 \\
\text { Employee } \\
\text { orientation and } \\
\text { socialisation }\end{array}$ & $\begin{array}{c}\text { Factor } 3 \\
\text { General } \\
\text { organisational } \\
\text { HR practices }\end{array}$ & \\
\hline 1 & Recruitment and advertising & 5.73 & .731 & & & \multirow[t]{2}{*}{.866} \\
\hline 2 & Employee selection & 6.54 & .878 & & & \\
\hline 3 & $\begin{array}{l}\text { Employee orientation and } \\
\text { induction }\end{array}$ & 2.11 & & .998 & & \multirow[t]{2}{*}{.771} \\
\hline 4 & Employee socialisation & 2.97 & & .541 & & \\
\hline 5 & $\begin{array}{l}\text { Psychometric and occupa- } \\
\text { tional testing }\end{array}$ & 3.43 & & & .594 & \multirow[t]{16}{*}{.949} \\
\hline 6 & $\begin{array}{l}\text { Performance management } \\
\text { and appraisal }\end{array}$ & 6.12 & & & .644 & \\
\hline 7 & $\begin{array}{l}\text { Career planning and devel- } \\
\text { opment }\end{array}$ & 4.49 & & & .692 & \\
\hline 8 & $\begin{array}{l}\text { Training, learning and devel- } \\
\text { opment }\end{array}$ & 3.89 & & & .612 & \\
\hline 9 & $\begin{array}{l}\text { Succession planning and } \\
\text { leadership development }\end{array}$ & 5.21 & & & .711 & \\
\hline 10 & Remuneration and reward & 5.71 & & & .761 & \\
\hline 11 & $\begin{array}{l}\text { Employment contracting and } \\
\text { individual bargaining }\end{array}$ & 4.61 & & & .650 & \\
\hline 12 & Collective bargaining & 3.48 & & & .525 & \\
\hline 13 & $\begin{array}{l}\text { The use of trial/probation } \\
\text { periods }\end{array}$ & 3.76 & & & .617 & \\
\hline 14 & $\begin{array}{l}\text { The use of part-time or flex- } \\
\text { ible labour }\end{array}$ & 4.94 & & & .637 & \\
\hline 15 & $\begin{array}{l}\text { Flexible working arrange- } \\
\text { ments }\end{array}$ & 4.49 & & & .677 & \\
\hline 16 & $\begin{array}{l}\text { Organisational change and } \\
\text { development }\end{array}$ & 3.44 & & & .690 & \\
\hline 17 & $\begin{array}{l}\text { Downsizing, restructuring } \\
\text { and redundancy }\end{array}$ & 4.80 & & & .939 & \\
\hline 18 & $\begin{array}{l}\text { Affirmative action and em- } \\
\text { ployment equity plans }\end{array}$ & 1.67 & & & .304 & \\
\hline 19 & $\begin{array}{l}\text { Empowerment plans (B- } \\
\text { BBEE) }\end{array}$ & 4.82 & & & .772 & \\
\hline 20 & Disciplinary procedures & 5.10 & & & .751 & \\
\hline
\end{tabular}


Table 4: Multiple regression analysis

\begin{tabular}{|c|c|c|c|}
\hline \multirow[t]{2}{*}{ Independent variables } & \multicolumn{3}{|c|}{$\begin{array}{l}\text { Susceptible Unethical HR Practices } \\
\text { as the Dependent variable }\end{array}$} \\
\hline & $\begin{array}{c}\text { Model 1* } \\
\text { (Factor 1) } \\
\text { Recruitment, } \\
\text { advertising } \\
\text { and selection }\end{array}$ & $\begin{array}{c}\text { Model2* } \\
\text { (Factor2) } \\
\text { Employee } \\
\text { orientation and } \\
\text { Induction }\end{array}$ & $\begin{array}{c}\text { Model 3 } \\
\text { (Factor3) } \\
\text { General } \\
\text { organisational } \\
\text { HR practices }\end{array}$ \\
\hline \multicolumn{4}{|c|}{ Factors influencing personal ethical behaviour } \\
\hline 1. Internal and external business influence: Factor 1 & 0.072 & 0.041 & 0.035 \\
\hline 2. Management influence: Factor 2 & 0.013 & 0.018 & -0.046 \\
\hline 3. Personal and professional standards influence: Factor 3 & $0.175 * *$ & -0.074 & 0.090 \\
\hline \multicolumn{4}{|c|}{$\begin{array}{l}\text { Degree of commitment to ethical business conduct exhibited by managers } \\
\text { and various groups in their organisations }\end{array}$} \\
\hline 1. CEO & 0.181 & 0.103 & $0.259^{*}$ \\
\hline 2. Senior management & -0.041 & 0.105 & 0.021 \\
\hline 3. Direct supervisor & -0.153 & -0.179 & -0.182 \\
\hline 4. Peers & -0.036 & -0.026 & -0.127 \\
\hline 5 Your direct reports & 0.058 & 0.032 & 0.059 \\
\hline 6. Employees in general & -0.111 & $-0.195 * *$ & -0.013 \\
\hline \multicolumn{4}{|l|}{$\begin{array}{l}\text { HR roles managing ethics in organ- } \\
\text { isations }\end{array}$} \\
\hline 1. HR department primary resource & -0.045 & $0.149 * *$ & -0.086 \\
\hline 2. HR cleaning up messes & $0.153 * *$ & 0.117 & $0.125^{*}$ \\
\hline 3. Charged with ethical oversight is qualified & $-0.158 *$ & 0.039 & -0.084 \\
\hline $\begin{array}{l}\text { 4. Resources and authority available to individual/ } \\
\text { department responsible }\end{array}$ & 0.100 & 0.075 & -0.005 \\
\hline 5. Employees know where to address ethical concerns & -0.058 & $-0.216 * *$ & -0.067 \\
\hline Adjusted $\mathrm{R}^{2}$ & .055 & .082 & .033 \\
\hline$F(p$ value $)$ & $1.98(.020)$ & $2.5(.003)$ & $1.57(.089)$ \\
\hline
\end{tabular}

Note: Standardised beta-coefficients are presented, statistical significance denoted with $* p<0.10 .{ }^{*} p<0.05$.

*Models 1, 2 and 3 represent Factors 1, 2 and 3 of the factor analysis (see Table 3) respectively 
the higher they would indicate the degree to which the HR practices of "recruitment, advertising and employee selection" practices were susceptible to unethical actions in the organisation. It can be deduced from this finding that the higher personal ethical standards of the practitioner together with the influence of ethical standards in the profession and the adherence to applicable legislation, the greater the sensitivity towards recruitment, advertising and selection practices in the organisation. This could imply that more attention will be given to 'rules and procedures' to prevent unethical practices, and the danger exists that a compliance approach will be taken rather than a more value-based approach to ethics.

b) The role of the HR function where HR professionals are not part of the ethics infrastructure but are tasked to 'clean up messes' caused by unethical actions (positive relationship $\mathrm{p}<0.05$, $\mathrm{b}=0.153)$. The more they agree that they are tasked to 'clean up messes' the stronger the degree to which they perceive that the HR practices of recruitment, advertising and selection practices could be susceptible to unethical HR practices. What is underscored is that HR practitioners are aware of possible unethical HR practices and/or that they might possess the skills and knowledge to rescue and normalise possible unethical HR practices when recruitment, advertising and selection decisions are made by line managers. The crucial roles respondents believe HR practitioners play, i.e. to ensure compliance and to curb unethical HR practices, is thus highlighted.

c) The more the respondents tend to disagree with the statement that the role of the HR function where the respondents are of the view that the "departments/individuals charged with ethical oversight is qualified for the task" (negative relationship $\mathrm{p}<0.10, \mathrm{~b}=$ -0.158), the more they perceive the degree of susceptible unethical HR recruitment, advertising and selection practices. This finding highlights the fact that in organisations where individuals/departments other than HR are tasked with ethical oversight, such individuals/departments are less qualified for the task, especially as required by the recruitment, advertising and selection processes.

\subsubsection{Unethical HR practices: Employee orientation and induction (Model 2)}

There were three instances where the degree to which the "employee orientation and induction practices" are susceptible to unethical HR practices were statistically significantly.

a) The respondents' views on the degree of "commitment to ethical business conduct" by employees in general (negative relationship $\mathrm{p}<0.05, \mathrm{~b}-0.195$ ). The more the respondents disagreed with this statement, the higher the degree to which they perceived susceptible unethical employee orientation and induction practices to be. The observation was that not adequate attention is given to the 'ethical conduct of employees in general' in organisations. Another possibility could be that these events were not well planned and executed by the HR department. There seems to be high value attached to the induction and orientation of newly recruited employees in organisations and for most, the first face-to-face encounter and exposure to an organisation's strategic and ethical focus, business philosophy and value system. The investment made to have a well-executed and honest overview of the organisational culture and other features during this phase could have a 
lasting effect on most employees in the organisation.

b) The role of the HR function where "the HR department is the primary resource for organisational ethics initiatives" (positive relationship $\mathrm{p}<0.05, \mathrm{~b}$ $=0.149$ ). The more the respondents agree that the HR function is the primary source of organisational ethics, the stronger the awareness that the employee orientation and socialisation practice could be susceptible to unethical HR practices. The respondents were confident that HR practices would be less susceptible and exposed to unethical actions of the HR department if the HR practitioners were the primary source to influence ethical behaviour in the HR. This finding supports the notion that in the case of HR, it is better for HR practitioners themselves to manage ethical HR practices. Other departments/individuals may not be as successful to curb unethical practices within the HR.

c) The role of HR where "employees in the organisation know where to address ethical concerns" (negative relationship $\mathrm{p}<0.05, \mathrm{~b}-0.216$.). The more the respondents disagreed the higher the degree to which they perceived susceptible unethical employee orientation and socialisation HR practices to exist. The respondents were of the view that for this item, employees did not know where to report ethical concerns. This could potentially indicate that unethical HR practices will not be adequately identified and resolved.

\subsubsection{Unethical HR practices: general organisational HR practices} (Model 3)

The degree to which general HR practices, for example performance management, career planning, training and development and employment relations, are susceptible to unethical HR practices are statistically significantly influenced by:

a) The commitment of ethical business conduct by the CEO of organisations (positive relationship $\mathrm{p}<0.10$, $\mathrm{b}=0.259)$. The more the respondents agreed that the CEO was committed to ethical business conduct, the stronger the awareness of the HR practitioners to identify susceptible unethical HR practices in their organisation. The very positive influence the CEO could have on the ethical culture of the HR functions within organisations was confirmed by this finding. In any organisation, the ethical standards of the CEO should influence not only HR practices but also the organisation as a whole. In organisations where CEOs are ethical leaders, the HR will be less susceptible to unethical practices.

b) The role of the HR function where HR professionals are not part of the ethics infrastructure but are tasked to 'clean up messes' caused by unethical actions (positive relationship $\mathrm{p}<0.10$, $\mathrm{b}=0.125)$. The more they agreed that they were tasked to 'clean up messes' the stronger the awareness that general HR practices could be susceptible to unethical HR practices. As reported earlier, the respondents were of the view that for models 1 and $2, \mathrm{HR}$ is well-equipped to improve ethical behaviour in the majority of HR practices in organisations.

\subsubsection{Independent variables: summary of results}

In this section a summary of results related to the independent variables is listed (see table 5).

- HR roles managing ethics in organisations: positively correlated scores were 
identified in three areas, namely where HR practitioners are directly involved with assisting to resolve susceptible HR ethical problems (Models 1, 2 \& 3). Negatively correlated scores were identified in two areas (Models $1 \&$ 2), namely where HR practitioners were not directly involved with solving possible ethical problems.

- The degree of commitment to ethical business conduct exhibited by managers and various groups in their organisations: A positive correlated score was identified in one area (Model 3), namely the more the respondents agreed that the CEO is committed to ethical business conduct, the stronger the awareness of the HR practitioners to identify susceptible unethical HR practices among general HR organisation practices. Negatively correlated scores were identified in the area (Model 2) where employees in general perceived susceptible unethical employee orientation and induction HR practices exist.

- Factors influencing personal ethical behaviour: A positively correlated score was identified in the areas of recruitment, advertising and selection practices (Model 1). The higher they rated the personal and professional influence, the higher they indicated the degree to which the HR practices of recruitment and advertising and employee selection practices are susceptible to unethical actions in organisation. It can be deduced from this finding that the higher personal ethical standards of the practitioner together with the influence of ethical standards in the profession and the adherence to applicable legislation, the greater the sensitivity will be towards recruitment, advertising and selection practices in organisation.

\subsection{CONCLUSION AND RECOMMENDATIONS}

The purpose of this study was to report on the views of HR practitioners on the susceptibility of unethical behaviour in HR practices in South African organisations. This was done to fill a gap in literature by providing insights regarding the areas where HR practices are susceptible to unethical practices and to suggest solutions, implications for practice and research recommendations for further consideration. Various statistical analyses were done, i.e. means were reported, and explorative factor analysis and a standard regression analysis were performed. A ranking-based means identified the following areas: employee selection, performance management and appraisal, recruitment and advertising, and remuneration and reward as most susceptible to unethical behaviour in HR practices. The areas least susceptible were affirmative action and employment equity plans, employee orientation and induction, employee socialisation and psychometric testing. The regression analysis revealed statistically significant differences in the area of recruitment, advertising and selection (Model 1) related to the influence of personal and professional standards and the role of HR. Secondly, employee orientation and induction (Model 2) specifically related to commitment to ethical business conduct (employees in general) and the role of HR. Lastly, general organisation HR practices (Model 3) related to commitment to ethical business conduct (CEO) and the role of the HR function.

The views of HR practitioners are clearly confirmed, as they believe that, if HR practitioners are directly involved in resolving an ethical dilemma (referred to the HR department or to an HR practitioner), ethical dilemmas will be resolved more 
effectively. If the ethical dilemma is referred to departments other than the HR, the other departments will be less successful in resolving it. HR as a department is consequently playing a less significant role in managing ethics in organisations. However, it could be the case that ethics is so important that separate departments or units are created to manage ethics. Whatever the case, HR practitioners were of the view that they were in the best position to identify and resolve HR ethical dilemmas.

The important role a CEO plays in creating an ethical culture was once again confirmed especially within the context of general HR practices. The respondents agreed that, if the CEO is committed to ethical business conduct, the awareness of the HR practitioners to identify susceptible unethical HR practices in the organisation, then the HR practices will be stronger. The respondents' views indicated that inadequate attention is given to the ethical conduct of employees in general, with specific reference to employee orientation and socialisation processes in organisations.

Another finding was that the higher the personal ethical standards of the practitioner, adherence to the ethical standards of the SABPP and applicable legislation are, the greater the sensitivity towards ethical recruitment, advertising and selection practices in organisations is. This finding confirms the power of ethical codes introduced by professional bodies, good personal ethics and the role of legislation.

Negatively correlated scores were identified in the area (Model 2) where "general employees" perceived susceptible unethical "employee orientation and induction" practices exist. More attention should be to given to "employee orientation and induction" practices and in particular how general employees are treated compared to more senior employees. First impressions will positively contribute to an ethical culture, and ethical employees ensure that work is completed with honesty and integrity and this should enhance the organisation's reputation for quality products and service (Kelchner, 2017).

This study was not without its limitations. Firstly, the population consisted of registered members of the South African Board of People Practice (SABPP) who are employed in different organisations in South Africa. Due to this, a representative sample of organisations in South Africa could not have been drawn. The majority of respondents in this study were employed in the education and training sectors and worked in organisations employing 1,000 or more people (see section 3.2 participant profile). Secondly, this study was conducted in South Africa and although the results cannot be generalised, specific HR functions which are more susceptible to unethical behaviour than others were identified. Despite these limitations, the present study makes a meaningful contribution to the literature on business ethics, in particular the area of possible susceptible unethical HR practices, the role of the HR function in managing ethics, personal standards and commitment to ethical standards. It is recommended that future research be replicated with broader samples across various organisations. In addition, the research could be repeated in organisations with less than 1,000 employees and within specific industries to obtain a more nuanced picture of the challenges.

The following managerial implications are highlighted. There is no doubt that, in pursuit of organisational ethics, leaders, managers and particularly HR practitioners at all levels should serve as role models and create an ethical culture before expecting 
employees to commit to and adopt ethical work practices. Professional HR bodies should be encouraged to enhance ethical professionalism of HR practitioners further through their various publications. The organisations should consider introducing an organisational ethical framework or architecture. This framework should allow for a holistic view on ethical interventions and challenges and the positioning of the HR department and its role. HR practitioners should continue to uphold ethical standards, specifically where the susceptibility of unethical HR practices are high. The practitioners could influence ethical behaviour positively although they might not be primarily responsible for the management of ethics

\section{References}

1. Abbott, P. (2015). Ethical issues in employment equity and transformation. In Abbott, P. (Ed.). Ethical competence in HR management practice. Johannesburg: Ethics Committee of the South African Board for People Practices.

2. Ardichvili, A., \& Jondle, D. (2009). Ethical business cultures: A literature review and implications for HRD, Human Resource Development Review, 8(2): 223-44.

3. Arshad, S.H. (2016). The role of the ethics in the management of the organization, International Journal of Management Sciences and Business Research, 5(8): 2226-35.

4. Barney, W. (2017). Geographies of African corruption, PSU Research Review, 1(1): 20-38.

5. Bernstein, R. (2016). Current ethical issues in business. [online] URL: https://online.shorter.edu/business/ current-ethical-issues-in-business/

6. Botha, C. (2015). Ethics in recruitment and selection. In Abbott, P. (Ed.). in organisations. HR practitioners should endeavour to establish strong partnerships with line managers and the ethics office in organisations. This could create an open and positive ethical environment where HR practitioners could creatively frame the advantages of an ethical organisation to allow all employees to aspire to and adopt an 'ethics for life' culture. The views of Caldwell et al. (2011: 171) are fully supported when they state that HR professionals "need to raise the standard of their performance and the competitive demands of the modern economic environment create implicit ethical duties that HR practitioners owe to their organizations".

Ethical competence in HR management practice. Johannesburg: Ethics Committee of the South African Board for People Practices.

7. Boyne, G.A. (2003). Sources of public service improvement: A critical review and research agenda, Journal of Public Administration Research and Theory, 13(3): 367-94.

8. Brown, M. (2015). Ethics in organizations. [online] URL: https:// www.scu.edu/ethics/ethics-resources/ethical-decision-making/ ethics-in-organizations

9. Brun, B. (2015). Ethical issues in measuring and verifying B-BEE. In Abbott, P. (Ed.). Ethical competence in HR management practice. Johannesburg: Ethics Committee of the South African Board for People Practices.

10. Caldwell, C., Truong, D., Linh, P.T. \& Tuan, A. (2011). Strategic human resource management as ethical stewardship, Journal of Business Ethics, 98: 171-82.

11. Corruption Watch. (2016). South Africa is not taking ethics seriously. [online] 
URL: http://www.corruptionwatch.org. za/corporate-sa-not-taking-ethics-seriously-enough/

12. Chartered Institute of Personnel and Development (CIPD), (2017). Business Ethics and the role of HR.[online] URL: https://www.cipd. co.uk/knowledge/culture/ethics/ role-hr-factsheet

13. De George, R.T. (2015). A history of business ethics. [online] URL: https://www.scu.edu/ ethics/focus-areas/business-ethics/ resources/a-history-of-business-ethics/

14. Den Hartog, D.N. (2015). Ethical leadership, The Annual Review of Organizational Psychology and Organizational Behavior, 2: 409-34.

15. Eisenbei, S., \& Brodbeck, F. (2014). Ethical and unethical leadership: A cross-cultural and cross-sectoral analysis, Journal of Business Ethics, 122(2): 343-59.

16. Erasmus, B.J., \& Wordsworth, R. (2004)16. Aspects of business ethics in South Africa, South African Journal of Labour Relations, 28(2): 77-112.

17. Erasmus, B.J., \& Wordsworth, R. (2006). The views of HR practitioners on ethical issues within organisations: A South African perspective, South African Journal of Economic and Management Sciences, 9(4): 413-28.

18. Ethics Centre. (2016). Ethical frameworks. [online] URL: http://www. ethics.org.au/on-ethics/blog/october-2016/ethical-frameworks-bringing-together-what-matters

19. Gallo, A. (2015). A refresher on regression analysis. [online] URL:https://hbr. org/2015/11/a-refresher-on-regressionanalysis

20. Ghani, B. (2015). Advance ethical practices in human resource management: A case study of health care company, Journal of Resources Development and Management, 5: 8-14.

21. Gibbons, P. (2015). Ethics in performance management. In Abbott, P. (Ed.). Ethical competence in HR management practice. Johannesburg: Ethics Committee of the South African Board for People Practices.

22. Greenwood, M. (2013). Ethical analyses of HRM: A review and research agenda, Journal of Business Ethics, 114: 355-66.

23. Greenwood, M.R. (2002). Ethics and HRM: A review and conceptual analysis, Journal of Business Ethics, 36: 261-78.

24. Grobler, A. (2016). An adapted measure of ethical climate in organisations: A Southern African study, African Journal of Business Ethics, 11(1): 1-21.

25. Groenewald, L. (2016). The South Africa Business Ethics Survey: Ethics Institute. [online] URL: https://www. tei.org.za/phocadownload/sabes2016FINAL.pdf

26. Hair, J.F., William, Black, W. C, Babin, B.J., \& Anderson, R.J. (2010). Multivariate Data Analysis, 7th Edition. London: Pearson.

27. Harned, P.J. 2005. When ethics calls the HR Helpline. In Losey, M., Meisinger, S. \& Ulrich, D. (Eds.). The future of human resource management. Alexandria, USA: Wiley.

28. Hiekkataipale, M., \& Lämsä, A. (2017). What should a manager like me do in a situation like this? Strategies for handling ethical problems from the viewpoint of the logic of appropriateness, Journal of Business Ethics, 145 (3): 457-79.

29. Hijal-Moghrabi, I., Meghna, S., \& 
Berman, E.M. (2015). The importance of ethical environment to organizational performance in employment at Will States, Administration \& Society, 1:1-29.

30. Honnet, M. (2015). Ethics in remuneration and reward. In Abbott, P. (Ed.). Ethical competence in HR management practice. Johannesburg: Ethics Committee of the South African Board for People Practices.

31. Ingram, D. (2017). The importance of ethics in human resources. [online] URL: http://smallbusiness.chron.com/ importance-ethics-human-resources-12780.html

32. Jondle, D., Ardichvili, A., \& Mitchell, J. (2014). Modeling ethical business culture: Development of the Ethical Business Culture Survey and its use to validate the CEBC Model of Ethical Business Culture, Journal of Business Ethics, 119(1): 29-43.

33. Kaptein, M. (2008). Developing a measure of unethical behavior in the workplace: A stakeholder perspective, Journal of Management, 34: 978-1008.

34. Kaptein, M. (2011). Toward effective codes: Testing the relationship with unethical behavior, Journal of Business Ethics, 99: 233-51.

35. Kaptein, M. (2015a). The effectiveness of ethics programs: The role of scope, composition, and sequence, Journal of Business Ethics, 132: 415-31.

36. Kaptein, M. (2015b). 'The battle for business ethics: A struggle theory', Journal of Business Ethics, 144: 1-54.

37. Kaptein, M., \& Schwartz, M.S. (2008). The effectiveness of business codes: A critical examination of existing studies and the development of an integrated research model, Journal of Business Ethics, 77(2): 111-127.
38. Karpoff, J.M, Lee, D.S., \& Martin, G.S. (2008). The cost to firms of cooking the books. Journal of Financial and Quantitative Analysis [online] URL: http://ssrn.com/abstract=652121.

39. Kelchner, L. (2017). The importance of ethics in organizations. [online] URL: http://smallbusiness.chron.com/importance-ethics-organizations-20925.html

40. Kleiman, L.S. (1997). Human resource management: A tool for competitive advantage. New York, NY: West.

41. Linehan, C., \& O'Brien, E. (2017). From tell-tale signs to irreconcilable struggles: The value of emotion in exploring the ethical dilemmas of human resource professionals, Journal of Business Ethics, 141: 763-77.

42. Lloyd, H., Mey, M., \& Ramalingum, K. (2014). Ethical business practices in the Eastern Cape automotive industry, South African Journal of Economic and Management Science, 5: 569-83.

43. Losey, M.R. (1997). The future human resource professional: Competency buttressed by advocacy and ethics. In Ulrich, D., Losey, M.R. \& Lake, G. (Eds.). Tomorrow's HR management: 48 thought leaders calling for change. New York, NY: Wiley.

44. Luiz, J. M., \& Stewart, C. (2014). Corruption, South African Multinational Enterprises and Institutions in Africa. Journal of Business Ethics. 124:383-398.

45. MacDonald, C. (2013). Why HR management is always ethically relevant. [online] URL: http://www.canadianbusiness.com/blogs-and-comment/ why-HR-management-is-always-ethically-relevant/

46. Markkula Center for Applied Ethics. (2017). Ethical decision making. [online] URL: https://www.scu.edu/ethics/ 
ethics-resources/ethical-decisionmaking/a-framework-for-ethical-decision-making/

47. Mitonga-Monga, J., \& Cilliers, F. (2016). Perceived ethical leadership in relation to employees' organisational commitment in an organisation in the Democratic Republic of Congo, African Journal of Business Ethics, 10(1): 36-51.

48. Morley, M. (2017). What are the major ethical issues business people face? [online] URL: http://smallbusiness. chron.com/major-ethical-issues-business-people-face-20900.html

49. Muleya, V.R., Fourie, L., \& Schlebusch, S. (2017). Ethical challenges in assessment centres in South Africa. SA Journal of Industrial Psychology, 43(0):a1324.

50. Ogwoka, M.D., Namada, J., \& Sikalieh, D.S. (2017). Effect of ethical human resource management practices on the financial performance of listed firms in the Nairobi Securities Exchange (NSE), European Journal of Human Resource, 1(1): 98-114.

51. Oster, K.V. (2017). List of ethical issues in business. [online] URL: http:// smallbusiness.chron.com/list-ethical-issues-business-55223.html

52. Pallant, J. (2013). SPSS survival manual: A step by step guide to data analysis using SPSS for Windows. 5th Edition. New York, NY: McGraw-Hill.

53. Parkes, C., \& Davis, A.J. (2013). Ethics and social responsibility - do HR professionals have the 'courage to challenge' or are they set to be permanent 'bystanders?', The International Journal of Human Resource Management, 24 (12), 2411-2434

54. Pardoe, I. (2017). Regression analysis. [online] URL: http://www.statistics. com/regression-analysis
55. Prasad, N., Kumar, V., \& Kapoor, S. (2017). Business ethics: A decision between right or wrong, Journal of Public Policy \& Environmental Management, 1(1): 20-30.

56. Rendtorff, J.D. (2018). Cosmopolitan business ethics: Towards a global ethos of management. Oxford: Routledge Taylor \& Francis Group.

57. Rose A. (2017). Ethics in human resource management. [online] URL:http://www.dphu.org/uploads/attachements/books/books_4824_0.pdf

58. Rossouw, R. (2011). Fighting corruption. [online] URL: https://www.tei. org.za/index.php/resources/articles/ business-ethics/2190-fighting-corruption

59. Ruiz, P., Martinez, R., Rodrigo, J., \& Diaz, C. (2014). Level of coherence among ethics program components and its impact on ethical intent, Journal of Business Ethics, 128(4): 725-42.

60. Sarker, A.S. (2017). Human resource management practices and employee performance in banking sector of Bangladesh. Journal of Human Resource Management. 1: 68-80

61. SABPP (South African Board for People Practices). (2017a). HR Competency Model. [online] URL: http://sabpp. co.za/sabpp-hr-competency-model/

62. SABPP (South African Board for People Practices). (2017b). SABPP Code of Ethics. [online] URL: http://sabpp.co.za/wp-content/ uploads/2016/12/SABPP_Code_of conduct.pdf

63. Saunders, M., Lewis, P., \& Thornhill, A. (2009). Research methods for business students. 5th Edition. Essex: Pearson Education.

64. Schminke, M., Arnaud, A., \& Kuenzi, M. (2007). The power of ethical work climates, Organizational Dynamics, 36: 171-83.

65. Schoeman, C. (2017). Creating an ethical culture in your organisation. 
In HR Voice. The official communication to all HR practitioners. South African Board for People Practices. [online] URL: http://sabpp.co.za/ sabpp-hr-voice/

66. Schwartz, M. (2013). Developing and sustaining an ethical corporate culture: The core elements, Business Horizons, 1: 39-56.

67. Shapiro, P. (2015). Ethical practices in learning and development. In Abbott, P. (Ed.). Ethical competence in HR management practice. Johannesburg: Ethics Committee of the South African Board for People Practices.

68. Shaw, W.H. (2017). Business ethics: A text book with cases. 9th Edition. Boston, MA: Cengage Learning.

69. Sims, R.R. (Ed.). (2017). A contemporary look at business ethics. Charlotte, NC: Information Age.

70. Singh, J.P. (2017). Business ethics in human resource management. Seminar report. Patiala: Punjab University.

71. Skeet, A. (2017). Is your company culture healthy? Six inquiries leaders can make to strengthen culture. [online] URL: https://www.scu. edu/ethics/leadership-ethics-blog/ is-your-company-culture-healthy/

72. Spence, L.J. (2014). Business ethics and social responsibility small business. In Chell, E. \& Karataş-Özkan, M. (Eds.). Handbook of research on small business and entrepreneurship. North Hampton, USA: Edward Elgar.

73. Svensson, G., \& Wood, G. (2011). A conceptual framework of corporate and business ethics across organizations: Structures, processes and performance, The Learning Organization, 18(1): 21-35.

74. Ulrich, D. (1997). Human resource champions: The next agenda for adding value and deliver results. Boston, MA: Harvard Business School Press.
75. Ulrich, D., \& Dulebohn, J.H. (2015). Are we there yet? What's next for HR? Human Resource Management Review, 25: 188-204.

76. Ulrich, W. (2017). Victory through organization: Why the war for talent is failing your company and what you can do about it. New York, NY: McGraw-Hill.

77. Van der Walt, F., Jonck, P., \& Sobayeni, N.C. (2016). Work ethics of different generational cohorts in South Africa, African Journal of Business Ethics, 10(1): 52-66.

78. Van Vuuren, L.J., \& Eiselen, R.L. (2006). A role for HR in corporate ethics? South African practitioners' perspectives. SA Journal of Human Resource Management, 4 (3): 22-28

79. Welsh, D.T., Ordóñez, L.D., Snyder, D.G., \& Christian, M.S. (2015). The slippery slope: How small ethical transgressions pave the way for larger future transgressions, Journal of Applied Psychology, 100(1): 114-27.

80. Wiley, C. (2000). Ethical standards for human resource management professionals: A comparative analysis of five major codes, Journal of Business Ethics, 25: 93-114.

81. Wooten, K.C. (2001). Ethical dilemmas in human resource management: An application of a multidimensional framework, a unifying taxonomy, and applicable codes, Human Resource Management Review, 11(1/2): 159-75.

82. Zuber, F., \& Kaptein, M. (2014). Painting with the same brush? Surveying unethical behaviour in the workplace using self-reports and observer-reports, Journal of Business Ethics, 125: 401-32. 


\section{NEETIČNO PONAŠANJE U PRAKSI UPRAVLJANJA LJUDSKIM RESURSIMA U JUŽNOJ AFRICI: POGLED IZ PRAKSE}

Sažetak

Istraživanje, koje se prikazuje u ovom radu, utvrđuje odnose između podložnosti neetičkog ponašanja u praksi upravljanja ljudskim resursima (kao zavisne varijable) i triju nezavisnih varijabli, i to: uloge funkcije ljudskih resursa $u$ institucionalizaciji poslovne etike; čimbenika, koji utječu na osobne etičke izbore praktičara ljudskih resursa te posvećenost etičnom ponašanju, kojeg pokazuju pojedinci i grupe unutar organizacija. Provedeno je deskriptivno istraživanje, korištenjem on-line upitnika, u kojem je sudjelovalo 304 južnoafričkih praktičara iz područja ljudskih resursa. Rezultati istraživanja pokazuju da su, s obzirom na neetičke prakse upravljanja ljudskim resursima, najosjetljivija područja selekcije, upravljanja performansama i procjenom istih, kao i regrutiranje te oglašavanje potreba za zaposlenicima. Područja ljudskih resursa, najmanje podložna neetičnim praksama su: pozitivne mjere prema manjinama, pravedno ponašanje prema zaposlenicima, orijentacija $i$ socijalizacija zaposlenika te psihometrijska testiranja. Rezultati također pokazuju statistički značajne odnose između nezavisnih varijabli $i$ zavisne varijable. Među ostalim rezultatima, pozitivan i statistički značajan odnos postoji između podložnosti neetičnim praksama upravljanja ljudskim resursima (u slučaju kada su praktičari ljudskih resursa sami odgovorni za rješavanje etičkih dilema), odnosno negativan (kada praktičari ljudskih resursa nisu direktno uključeni u rješavanje etičkih dilema). Funkcija upravljanja ljudskim resursima ima značajnu ulogu i doprinosi institucionaliziranju poslovne etike u organizacijama.

Ključne riječi: upravljanje ljudskim resursima, etika, Južna Afrika, pogled praktičara ljudskih resursa 